\title{
Spot urine protein/creatinine ratio is associated with 24-hour proteinuria and serum albumin
}

\section{Spot idrar protein/kreatinin oranı, 24 saatlik idrarda proteinüri ve serum albumin ile ilişkilidir}

\author{
Ozlem ALKAN ${ }^{1}$, Abdullah OZKOK ${ }^{1}$, Hande OZPORTAKAL ${ }^{1}$, Ahmet Sait BULUT $^{1}$, Ferruh ISMAN ${ }^{2}$, Ali Riza ODABAS $^{1}$
}

\begin{abstract}
Proteinuria is an important risk factor for renal and cardiovascular diseases. In nephrology practice, treatment decisions are made according to proteinuria levels. Inconstinencies in the measurements of proteinuria with different methods such as urinalysis, spot urine protein to creatinin ratio $(P C R)$ and 24-hour-urine proteinuria lead to confusion in the management of the patients. Herein, we aimed to compare these three proteinuria measurement methods within themselves, and serum albumin levels, and evaluate existing correlations. A total of 1038 urine tests were evaluated. Urinalysis was performed using FUS-200/H-800 fullautomatic urinalysis system. Spot urine PCR and 24-hour-urine proteinuria were measured turbidometrically. Serum albumin concentrations were measured photometrically. Urine samples with more than 10 leukocytes or erythrocytes in urine sediments were not included in the analysis.. Proteinuria detected with urinalysis was significantly associated with spot urine PCR $(r=0.75$, $p<0.001), 24$-hour proteinuria $(r=0.76, p<0.001)$ and serum albumin levels $(r=-0.36, p<0.001)$. In patients with $3+$ proteinuria in urinalysis, urine PCR was measured as 5.59 (2.76-9.11) g/day; 24-hour proteinuria, 4.54 (2.85-9.05) g/day and serum albumin level, $3.08 \pm 0.86 \mathrm{~g} / \mathrm{dL}$. Spot urine $P C R$ was significantly correlated with 24 -hour proteinuria $(r=0.80, p<0.001)$. Both spot urine $P C R$ and 24-hour proteinuria were significantly and negatively correlated with serum albumin levels $(r=-0.54, p<0.001$ and $r=-$ $0.54, p<0.001$, respectively). Spot urine PCR obtained from both morning and afternoon samples were significantly associated with 24-hour proteinuria ( $r=0.83, p<0.001$ and $r=0.82, p<0.001$ respectively). All three methods of measurement for proteinuria were significantly associated with each other and serum albumin levels. Spot urine PCR is an easy and reliable method for measurement of proteinuria.
\end{abstract}

Keywords: Proteinuria, urinalysis, urine spot protein-to-creatinine ratio, 24-hour urine proteinuria

\section{Giriş}

Proteinüri, renal ve kardiyovasküler hastalıklarda önemli bir prognostik belirteç olarak bilinmektedir ${ }^{1}$. öz

Proteinüri, renal ve kardiyovasküler hastalıklarda önemli bir risk faktörüdür. Nefroloji pratiğinde, hastaların tedavileri proteinüri seviyelerine göre düzenlenmektedir. Bazı durumlarda tam idrar tahlili (TiT), spot idrar protein/kreatinin oran (PKO) ve 24-saatlik idrar proteinüri ölçümlerinde görülen tutarsızlıklar, hastaların tedavilerinin düzenlenmesi sırasında kafa karışılığına yol açmaktadır. Bu çalışmamızda, bu üç proteinüri ölçüm yönteminin kendi arasında ve serum albümin seviyeleriyle karşılaştırılması ve korelasyonlarının değerlendirilmesi amaçlanmıștır. Toplam 1038 idrar örneği değerlendirildi. TiT, FUS-200/H-800 Tam Otomatik idrar Analiz Sistemi kullanılarak çalışıldı. Spot ve 24-saatlik idrar örneklerinde proteinüri, turbidimetrik olarak ölçüldü. Serum albümin konsantrasyonu fotometrik renk testi ile ölçüldü. Idrar sedimentinde >10 lökosit veya eritrositi olan idrar örnekleri çalışmaya dahil edilmedi. TiT'deki proteinüri miktarı, spot idrar PKO $(r=0.75, p<0.001), 24$ saatlik proteinüri $(r=0.76, p<0.001)$ ve serum albümin $(r=-0.36, p<0.001)$ seviyeleri ile anlamlı olarak ilişkiliydi. TiT'de 3+ proteinüri saptanan hastaların median spot idrar PKO'su 5.59 (2.76-9.11) g/gün, 24 saatlik proteinüri 4.54 (2.85$9.05) \mathrm{g} / \mathrm{gün}$ ve ortalama serum albumin seviyesi $3.08 \pm 0.86 \mathrm{~g} / \mathrm{dL}$ olarak belirlendi. Spot idrar PKO ile 24 saatlik proteinüri anlamlı olarak ilişkili bulundu $(r=0.80, p<0.001)$. Hem spot idrar PKO hem de 24-saatlik proteinüri, serum albumin ile anlamlı olarak ters korele bulundu(sırasıly $r=-0.54, p<0.001$ ve $r=-0.54, p<0.001$ ). Hem sabah hem de öğleden sonra alınan spot idrar PKO ile 24 saatlik proteinürinin anlamlı olarak ilişkili olduğu gözlendi (sırasıyla $r=0.83, p<0.001$ ve $r=0.82, p<0.001$ ). Her üç proteinüri ölçüm yöntemi de birbirleriyle ve serum albumin seviyeleri ile anlamlı olarak ilişkilidir. Günün herhangi bir saatinde alınan spot idrar PKO, proteinüri ölçümünde kolay ve güvenilir bir yöntem olarak kullanılabilir.

Anahtar kelimeler: Proteinüri, tam idrar tahlili, spot idrar proteinkreatinin oranı, 24-saat proteinüri

Nefroloji pratiğinde, proteinüri miktarı, hastaların tedavilerinin düzenlenmesi sırasında ilk planda dikkate alınan parametrelerdendir. Bazı durumlarda tam idrar tahlili (TiT), spot idrar protein/kreatinin oranı (PKO)

Received: 09.05.2016

Accepted: 08.09.2016

Istanbul Medeniyet University, Goztepe Training and Research Hospital, ${ }^{1}$ Department of Internal Medicine and Nephrology, ${ }^{2}$ Department of Biochemistry Yazışma adresi: Abdullah Özkök, Istanbul Medeniyet University, Goztepe Training and Research Hospital, Department of Internal Medicine and Nephrology Kadıköy, Istanbul

e-mail: abdullahozkok@yahoo.com

Bu çalışma, 32. Ulusal Nefroloji, Hipertansiyon, Diyaliz ve Transplantasyon Kongresi'nde poster olarak sunulmuştur (21-25 Ekim 2015, Antalya). 
ve 24 saatlik idrar proteinüri ölçümlerinde görülen tutarsızlıklar, hastaların tedavilerinin düzenlenmesi sırasında kafa karışıklığına yol açabilmektedir. Bununla birlikte, 24 saatlik idrar toplamanın konforsuz olduğu, toplama şartları göz önünde bulundurulduğunda hastalar arasında standart olmayacağını ve bu durumun klinisyeni yanlış yönlendirebileceğini düşünülebilir. Bu nedenle spot idrar PKO'nun daha kolay ve güvenilir bir yöntem olabileceği düşünülebilir. Bu çaIışmamızda, spot idrarda P/K oranı, 24 saatlik idrarda proteinüri, spot idrarda nitel protein ölçümünü kendi aralarında ve serum albumin seviyesi ile karşılaştırmayı ve korelasyonunu değerlendirmeyi amaçladık.

\section{GEREÇ ve YÖNTEM}

Çalışmaya Aralık 2013-Ağustos 2015 tarihleri arasında yapılan 1038 idrar tetkiki dahil edildi. Hastaların 24 saatlik idrar örnekleri, sabah ilk idrar atıldıktan sonra 24 saat boyunca, ertesi gün sabah ilk idrar örneği de dahil edilmek üzere toplandı. Spot idrar örnekleri ise randomize olarak toplandı. Hastaların öğleden önce ve sonra olmak üzere verdiği idrar örnekleri belirlendi.

Tam idrar tahlili (TIT), FUS-200/H-800 tam otomatik idrar analiz sistemi (Diuri, Çin) kullanılarak çalışıldı. Spot ve 24 saatlik idrar örneklerinde proteinüri, turbidimetrik olarak Abbott Architect C8000 otoanalizöründe ticari kitler kullanılarak ölçüldü (Abbott Laboratories, USA). Serum albumin konsantrasyonu fotometrik renk testi ile Beckman Coulter (ABD) ticari kitleri kullanılarak Olympus AU2700 (Hamburg, Almanya) otoanalizöründe ölçüldü.

Proteinüri düzeylerini etkileyebileceği düşünülerek idrar sedimentinde $>10$ lökosit veya eritrositi olan idrar örnekleri çalışmadan dışlandı. Bu çalışma yerel etik kurulumuz tarafından onaylanmıştır (2016/0124).

\section{İstatistiksel Analiz}

Toplanan veriler bilgisayar ortamında IBM SPSS 21.0 (Statistical Package for Social Science) programına aktarılmış ve gerekli düzeltmeler ve hata kontrolleri yapılmıştır. Normal dağılan değişkenler ortalama standart sapma olarak, normal dağılmayan değişkenler ise median (inter-quartile range \%25-75) şeklinde verilmiştir. Sürekli değişkenlerin analizinde verilerin dağılımına göre parametrik dağılan verilerde bağımsız örneklerde student t-testi, nonparameterik verilerde ise Mann Whitney $U$ testi kullanılmıştır. DağıIımların normalliği veya varyansların homojen olma şartlarının sağlanamadığı durumlarda Kruskal Wallis analizi uygulandı. Korelasyon değerlendirilmelerinde Pearson ve Spearmann korelasyon testleri kullanıldı. Spot idrar ve 24-saatlik proteinüri ölçümlerinin karşılaştırılması ve kabul edilebilirlik düzeyinin yorumlanması için Bland-Altman analizi referanstaki çalışmaya göre yapıldı ve Bland-Altman grafiği çizdirildi². Analizlerde, 0.05 'ten küçük olan $p$ değerleri anlamlı kabul edildi.

\section{BULGULAR}

Ortalama serum albümin seviyesi $3,55 \pm 0,78 \mathrm{~g} / \mathrm{dL}$, median spot idrar PKO 1,58 (0,47-4,19) g/gün, 24 saatlik proteinüri ise $1,30(0,46-3,13) \mathrm{g} /$ gün olarak belirlendi. TiT'deki proteinüri miktarı, spot idrar PKO $(r=0,75$, $p<0,001), 24$ saatlik proteinüri $(r=0,76, p<0,001)$ ve serum albumin $(r=-0,36, p<0,001)$ seviyeleri ile anlamlı olarak ilişkiliydi. TiT'de 3+ proteinüri saptanan

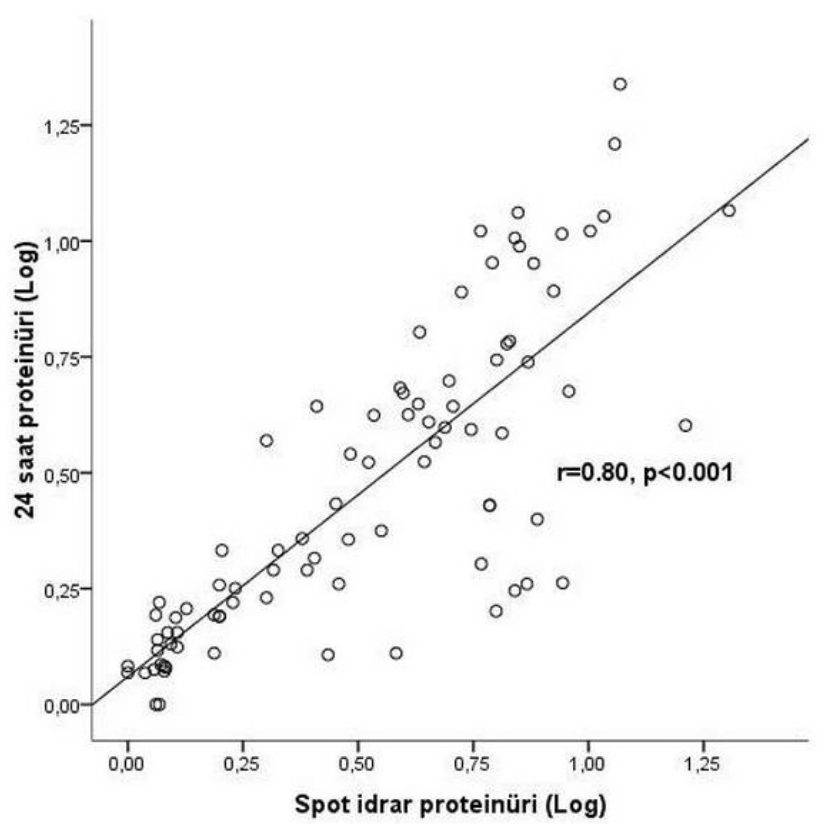

Figür 1. Spot idrar protein/kreatinin oranı, 24 saatlik idrarda protein ile anlamlı olarak ilişkilidir. 
hastaların median spot idrar PKO'su 5,59 $(2,76-9,11)$ g/gün, 24 saatlik proteinüri 4,54 (2,85-9,05) g/gün ve ortalama serum albümin seviyesi $3,08 \pm 0,86 \mathrm{~g} / \mathrm{dL}$ olarak belirlendi. Spot idrar PKO ile 24 saatlik proteinüri anlamlı olarak ilişkili bulundu $(r=0,80, p<0,001)$ (Figür 1). Hem spot idrar PKO hem de 24 saatlik proteinüri,

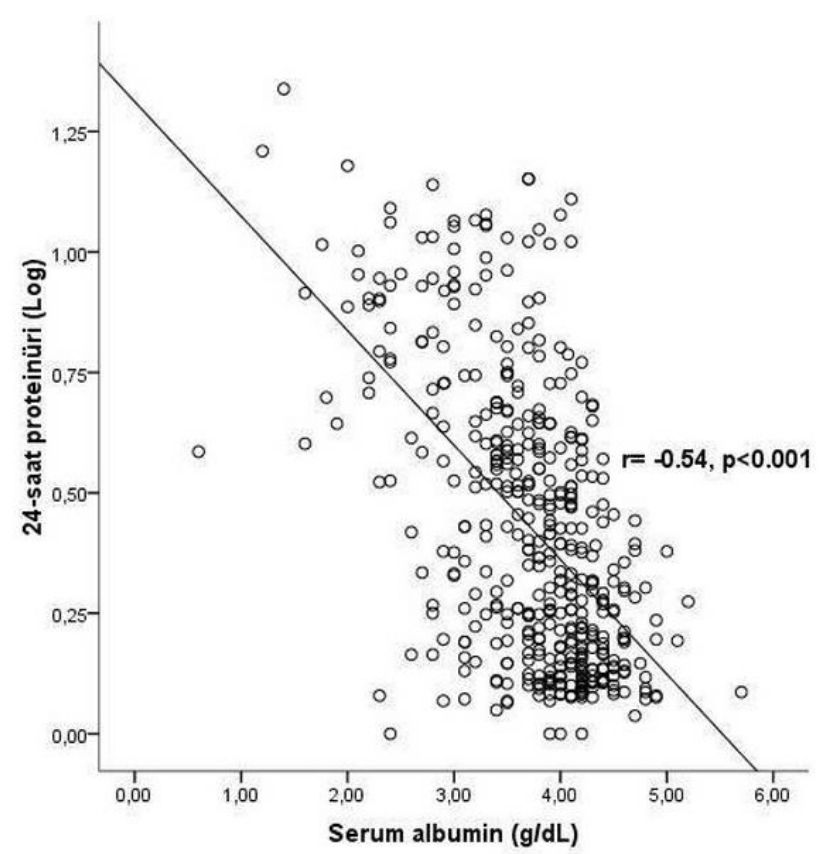

Figür 2. Serum albümin seviyeleri, 24 saatlik idrarda proteinüri ile anlamlı olarak ters ilişkilidir.

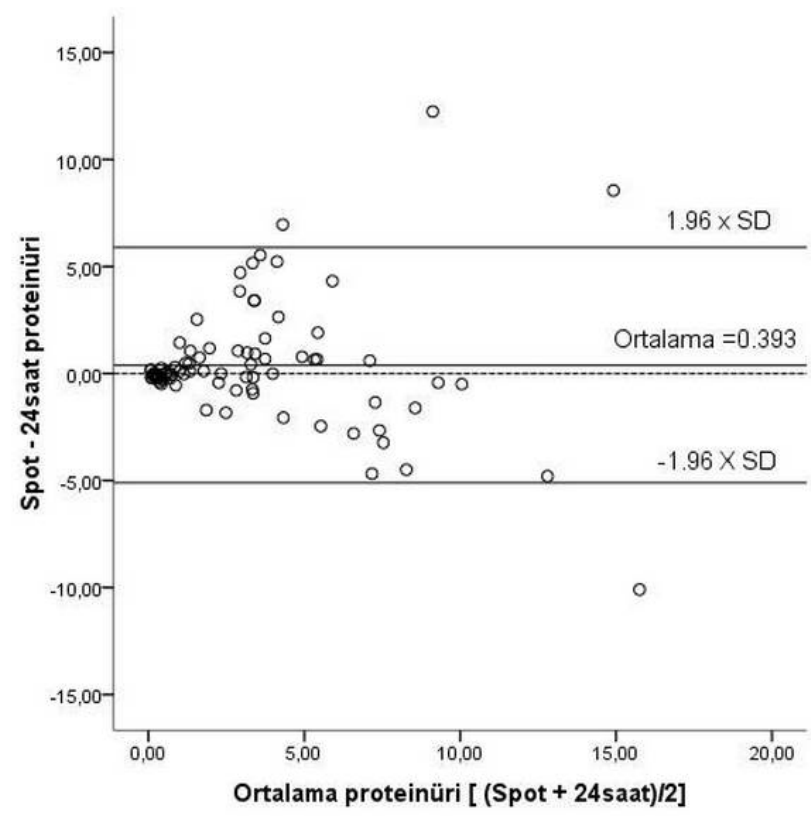

Figür 3. Spot idrar protein/kreatinin oranı, 24 saatlik idrarda protein ölçümlerinin Bland-Altman analizi. serum albumin ile anlamlı olarak ters korele bulundu (sırasıyla $r=-0,54, p<0,001$ ve $r=-0,54, p<0,001$ ) (Figür 2). Hem sabah hem de öğleden sonra alınan spot idrar PKO ile 24 saatlik proteinürinin anlamlı olarak ilişkili olduğu gözlendi (sırasıyla $r=0,83, p<0,001$ ve $r=0,82, p<0,001)$. Tiт'de 1+ ve daha düşük proteinürisi olan hastalarda spot idrar PKO, 24 saatlik proteinüri ile anlamlı olarak koreleydi $(r=0,89, p<0,001)$. TiT'de $3+$ proteinürisi olan hastalarda da bu ilişki devam ediyordu $(r=0,75, p<0,001)$. Spot idrar ve 24 -saatlik proteinüri ölçümlerinin karşılaştırılması ve kabul edilebilirlik düzeyinin yorumlanması için Bland-Altman analizi yapıldı ve Bland-Altman grafiği çizdirildi (Figür 3). Buna göre ölçümler arasındaki farklılıkların $>\% 95$ 'inin kabul edilebilir limitler dahilinde olduğu belirlendi.

\section{TARTIŞMA}

Proteinüri ölçümleri, son dönemlerde ciddi bir toplumsal sorun haline gelen kronik böbrek hastalığının (KBH) tanısında ve takibinde çok önemli tetkiklerdir. Türk Nefroloji Derneği tarafından yapılan çalışmaya göre, Türkiye'de KBH'nın 2002'deki prevalansı \%7 iken, 2012'de \%14'e yükselmiştir ${ }^{3}$. Renal hastalık oluşma riski yüksek olan hastalarda idrarda protein atılımının düzenli olarak taranmasını önerilmektedir ${ }^{4}$. Günlük pratikte tarama testi olarak TiT ile proteinüri saptanması kullanılmakta, kantitatif değerlendirme içinse protein atılımı sirkadiyen bir ritm gösterdiğinde 24 saatlik idrarda protein saptanması altın standart olarak kabul edilmektedir ${ }^{5}$. Ancak 24 saatlik idrar biriktirmek, günlük yaşam ve çalışma şartları göz önünde bulundurulduğunda hastalar açısından son derece konforsuz bulunmakta ve idrar örneklerinin doğru toplanmaması ise klinisyeni yanlış yönlendirmektedir. Bu nedenlerden dolayı, günümüzde alternatif bir yöntem olarak spot idrar protein/ kreatinin (P/K) oranı kullanılmaya başlanmıştır. Yapılan pek çok çalışmada, spot idrarda saptanan $\mathrm{P} / \mathrm{K}$ oranının 24 saatlik idrarda ölçülen günlük protein kaybı ile kolere olduğu ileri sürülmüştür ${ }^{6-10}$. Bu çalışmalara paralel olarak, biz de hastanemizde yapılan TiT, 24 saatlik idrarda proteinüri ve spot idrarda PKO'nın birbirleriyle anlamlı olarak ilişkili olduğu gözlemledik. Bunun ya- 
nında, her üç ölçümün de serum albumin seviyeleriyle ters korele olduğunu saptadık.

Yaptığımız Bland-Altman analizi ile spot idrar ve 24-saatlik proteinüri ölçümlerini karşılaştırdık ve ölçümler arasındaki farklılıkların kabul edilebilirlik düzeylerini yorumladık. Buna göre, ölçümler arasındaki farklılıkların $>\% 95$ 'inin kabul edilebilir limitler dahilinde olduğu belirlendi. Spot idrarda proteinüri ölçümü, daha eski bir metod olan 24 saatlik idrarda proteinüri ölçümüyle karşılaştırıldığında kabul edilebilir bir yöntem olarak ortaya çıkmaktadır.

Spot idrar PKO, spot (anlık) ya da sabah ilk idrar örneklerinden yapılabilmektedir ve idrar örneğinin alınma zamanının önemi konusunda literatürde çalışma bulunmamaktadır. Bu çalışmamızda, hem sabah hem de öğleden sonra alınan spot idrar PKO'nun 24 saatlik proteinüri ile anlamlı olarak ilişkili olduğu gözlemledik. Bu sonuçtan hastanın spot idrarını sabah ilk idrar şeklinde vermesinin gerekli olmadığı, gün içinde herhangi bir zamanda verilen idrar örneğinde PKO'nun da 24 saatlik proteinüriyi iyi bir şekilde predikte edebildiği çıkarımlanabilir. Bu bulgumuzun klinik pratikte, hastaları tetkikinde önemli bir esneklik ve rahatlık sağlayabileceğini düşünüyoruz.

Sonuç olarak, her üç proteinüri ölçüm yöntemi de birbirleriyle ve serum albümin seviyeleri ile anlamlı olarak ilişkilidir. Günün herhangi bir zamanında verilen spot idrarda protein/kreatinin oranı, proteinüri ölçümünde kolay ve güvenilir bir yöntem olarak kullanılabilir.

\section{REFERANSLAR}

1. Barnas U, Schmidt A, Haaa M et al. Parameters associated with chronic renal transplant failure. Nephrol Dial Transplant 1997;12:82-85. (PMID: 9269707)

2. Bland JM, Altman DG. Statistical methods for assessing agreement between two methods of clinical measurement. Lancet 1986;1(8476):307-10. (PMID: 2868172) https://doi.org/10.1016/S0140-6736(86)90837-8

3. Serdengeçti K, Süleymanlar G, Altıparmak MR, Seyahi N. Türkiye'de Nefroloji-Diyaliz ve Transplantasyon. Registry 2010. İstanbul, Türk Nefroloji Derneği Yayınları, 2011: 1-84.

4. National Kidney Foundation. K/DOQI Clinical Practice Guidelines For Chronic Kidney Disease: Evaluation, Classification and Stratification. Am J Kidney Dis 2002;39(Suppl 1):1-266. (PMID: 11904577)

5. Koopman MG, Krediet RT, Koomen GCM et al. Circadian rythm of proteinuria: consequences of the use of protein: creatinine ratios. Nephrol Dial Transplant 1989;4:9-14. (PMID: 2494607)

6. Ginsberg JM, Chang BS, Matarese RA, Garella S. Use of single voided urine samples to estimate quantitative proteinuria. New Engl J Med 1983;309:1543-1546. https://doi.org/10.1056/NEJM198312223092503

7. Evans W, Lensmeyer JP, Kirby RS et al. Two-hour urine collection for evaluating renal function correlates with 24-hour urine collection in pregnant patients. J Matern Fetal Med 2000;9:233-237. (PMID: 11048835) https://doi.org/10.1002/1520-6661(200007/08)9:4<233:: AID-MFM9>3.0.CO;2-S

8. Durnwald C, Mercer B. A prospective comparison of total protein/creatinine ratio versus 24 -hour urine protein in women with suspected preeclampsia. Am J obstet Gynecol 2003;189:848-852. https://doi.org/10.1067/S0002-9378(03)00849-4

9. Chitalia VC, Kothari J, Wells EJ et al. Cost-benefit analysis and prediction of 24-hour proteinuria from the spot urine protein-creatinine ratio. Clin Nephrol 2001;55:436-447. (PMID: 11434354)

10. Mitchell SCM, Sheldon TA, Shaw AB. Quantification of proteinuria: a re-evaluation of the protein/creatinine ratio for elderly subjects. Age Ageing 1993;22:443-449. https://doi.org/10.1093/ageing/22.6.443 